\title{
The Value and Risk Relevance of Fair Value: The Case of French Firms
}

\author{
Mondher Kouki \\ Associate Professor of Finance, Department of Accounting and Finance \\ Faculty of Economics and Management of Tunis \\ University Tunis Elmanar, Tunisia
}

Mosbeh Hsini (Corresponding author)

Assistant Professor of Finance, Department of Accounting and Finance

Higher Institute of Commerce and Accountancy of Bizerte, Carthage University, Tunisia

Email: lahsinim@gmail.com

Farah Tabassi

Research Assistant, Department Of Accounting And Finance

Faculty of Law, Economics and Management of Jendouba, Tunisia

Received: June 28, 2016 Accepted: July 12, 2016 Published: August 03, 2016

doi:10.5296/ijafr.v6i2.9692 URL: http://dx.doi.org/10.5296/ijafr.v6i2.9692

\begin{abstract}
We study the performance of fair value accounting standards of financial instruments starting from the analysis of quality relevance of accounting information. In particular, we are interested in the value relevance and risk relevance of income that contains financial instruments measured or not at fair value. To do so, we compare three income levels known as accounting standard's history. The three major levels are Full-Fair-Value income measurement (all-fair-value changes recognized in income), piecemeal-fair-value income measurement or comprehensive income (some fair-value changes recognized in income), and historical-cost income measurement or net income (no fair-value measurement existing). The empirical tests of value relevance showed that net income is not a relevant value, and Full Fair Value Income is more significant than the Comprehensive Income. The study shows also
\end{abstract}


that risk relevance is more, measured by the volatility of Full Fair Value Income.

Keywords: Fair value, Financial instrument, Value relevance, Risk relevance, IAS39

\section{Introduction}

The 'fair value' is not a recent concept. It was introduced in the United States' as Accounting Principles (US-GAAP) in 1975 by financial Accounting standards (FAS 12) related to accounting for investment securities. Moreover, a close concept is defined as "market value" and was used by the International Accounting Standards Board (IASB). Furthermore, the use of fair value was also, developed in the U.S standards of financial instruments (FAS 107, 115, 119, 125 and 133) and international standards of financial instruments (IAS 32 and IAS 39). This principle of fair value rises the recognition of unrealized gains and losses of some assets and liabilities in the income statement.

Before IAS 39, there have been no process accounting standards for financial instruments. Recognition assets and liabilities at fair value has been largely shifted to financial instruments. During the 1990s, the concept of fair value was used regularly in accounting standards and measurements of financial instruments. This is explained by the fact that the old principle of "historical cost" is no longer able to translate the reality of the firm, mainly for commercial banks which are composed of a large extent of financial instruments. The historical cost does not take into consideration changes in the price structure and the effects of interest rate variation on the value of private debt in the long term (Barlev and Haddad, 2003). FASB and IASB mentioned in their standards that fair value, as an evaluation method is more relevant than historical cost. Yet, several academic researches defended the concept of fair value since it provided more recent value and informs investors about the value creation and the company wealth (Barth et al. 1994, Nelson 1996, Hirst et al. 2004).

The financial crisis of 2008 has revived again the measurement problem of financial instruments, and posed doubts about the relevance of fair value accounting. This crisis highlights the potential volatility due to the fair value measurement of financial instruments. This is explained really that the fair value is pro-cyclical (Laux and Leuz, 2009). The income based on fair value measurement is more volatile than the income based on historical cost measurement (Hodder et al. 2006, Al-Khadash. and Al-yassen. 2011).

Accordingly, the academic studies give more explanation of the recent financial crisis by arguments related to fair value. Laux and Leuz (2009) argue that the pro-cyclicality of fair value intensifies fluctuation in the financial system and may cause a downward spiral in the financial markets. Thus, Laux and Leuz (2010) show in their analysis that during crisis, banks use the flexibility measurement of the asset fair value to justify their own judgments. Whereas, Beltratti et al. (2013) maintain that when write-downs ${ }^{1}$ occurred during financial crisis, many firms do not apply the fair value standards' flexibility in order to avoid or delay the market price valuation. This analysis brings us to the controversy whether the recognition

\footnotetext{
${ }^{1}$ A Write-down is the accounting term, used to describe a decrease in the book value of an asset due to real fluctuation in the asset.
} 


\section{MInstitute ${ }^{\text {Mink }}$}

International Journal of Accounting and Financial Reporting ISSN 2162-3082

of the estimated fair value of financial assets is a problem or a solution to the relevance of financial information.

The paper objective is to investigate to what extent the income measure (which takes account of change in fair value of financial instruments) is relevant to investors. To achieve this end, we compare three different income measures: Full-Fair-Value income measurement (all-fairvalue changes recognized in income), piecemeal fair value (some fair-value changes recognized in income), and historical-cost income measurement (any measures at fair-value exists).

Our research combines between two types of research known by several academic studies which is the value relevance and the risk relevance of fair value accounting. Furthermore, our research is closely linked to Hodder et al.. (2006), Duh et al. (2012) and Hirst et al. (2004). Hodder et al. (2006) have studied risk relevance of three income measures taking commercial banks as a sample by measuring the relation between supplementary volatility of income measurement, market model beta, the standard deviation of stock returns and beta interest rate. Duh et al. (2012) have also used credit rating as a market variable to study the relevance of comprehensive income. Hirst et al. (2004) have examined whether and how fair-value income measurement affects commercial bank equity analysts' risk and value judgments.

\section{Literature Review and Hypotheses Development}

The literature related to our topic has considered two types of income measures, containing a fair value change of financial instruments: Comprehensive income (IAS 1 IASB and FAS 130 IASC) and full fair value income (IAS39 IASB). Comprehensive income (CI) includes net income by adding unrealized gains and losses available-for-sale financial assets and gains and losses on derivatives qualified as hedges cash flow. The full fair value income (FFVI) contains a broader fair value measurement of financial instruments. It is composed of comprehensive income, in addition to gains and losses held for trading assets and financial instruments at fair value option.

The literature of relevance can be divided into two extended studies that examined value relevance and the risk relevance of accounting variable.

\subsection{Studies of value relevance}

Historically, the study of fair value accounting's relevance has started with Barth et al. (1994) who demonstrated how gains and losses changes securities investment fair value are included in shares prices compared to valuation of securities investment at their historical cost. They concluded that securities investments fair value accounting have a significant explanatory power, more than the securities historical investments cost accounting. Thus, securities investments fair value has less error measurement than securities' historical investments cost about amount reflected in stock price (Hirst et al.. 2004).

However, studies of the standard SFAS157's relevance were positive (Nelson 1996, Barth et al. 1996). Nelson (1996) found that fair value assets provide more expected market capitalization. Barth et al. (1996) and Khurana and Kim (2003) demonstrated that fair value 


\section{MInstitute Macrothink $_{\text {Int }}$}

International Journal of Accounting and Financial Reporting

ISSN 2162-3082

2016, Vol. 6, No. 2

has an informative significance superior to historical cost. Relevance of fair value loans varies according to the bank's financial situation (Barth et al. 1996). Also, Beltratti et al. (2013) held that fair value and aggregate write-downs are associated with stock return during the financial crisis. Thus, some financial instruments based on fair value are not relevant. Khurana and Kim (2003) mentioned that the relevance of fair value accounting is detected only for trading securities on liquid and complete markets (in particular AFS securities) for large banks.

The above analysis explains the debate about the role of the accounting income's relevance value in the evaluation dimension of the fair value mainly in financial assets and liabilities. In this context, our first hypothesis is:

$\boldsymbol{H}_{1}$ : value relevance of accounting income has an increasing function in the fair value evaluation dimension of financial assets and liabilities (FFVI $>C I>N I)$.

Where NI is the net income for firm, CI is the comprehensive income of firm. FFVI is the full fair value income of the firm.

\subsection{Studies of risk relevance}

Some authors consider that the transition to fair value accounting does not provide a complete measure of performance, but introduces artificial volatility on the accounting valuation of the patrimony and the performance of the company. Nevertheless, it creates a sense of confusion between the results directly related to management decisions and that which come from market fluctuations. Numerous studies have shown that the recognition of changes in fair value creates volatility in accounting income. Fair value is the present value of future cash flows (SFAS 157). Therefore, these changes reflect Transformation in expectations associated with these cash flows that may lead to increased volatility in earnings (Barth et al. 1995).

A more detailed explanation of the causes of this volatility is explained by Barth and Landsman (1995). The fair value of an asset or liability is the present value of future cash flows, which depends on the discount rate. The latter depends on the credit risk. Thus, if the debt becomes riskier, the appropriate discount rate becomes higher and the debt value decreases if the contractual interest rate is not adjusted for debt risks. The income based on fair value measurement is more volatile than income-based historical cost measurement (AlKhadash. and Al-yassen. 2011). In addition, Hodder et al. (2006) found that income volatility in the fair value is three times higher than that of comprehensive income and is more than five times higher than net income.

Indeed, several previous studies (Barth et al, 1995, Hodder et al., 2006; Ryan, 2008; Duh et al. 2012) do suggest that the application of fair value accounting for financial instruments can improve the relationship between the boundary of market risk and earnings volatility. AlKhadash. and Al-yassen. (2011) stressed that all measures of income volatility in the fair value can be a suitable indicator of overall risk.

Most previous studies on the relevance of accounting income's volatility are held around the US accounting standards. Duh et al., (2012) were the pioneer who studied this issue in 


\section{MInstitute Macrothink $_{\text {Int }}$}

International Journal of Accounting and Financial Reporting ISSN 2162-3082

accordance with IFRS and the association between credit ratings and long-term income volatility before and after the adoption of IFRS. They find that the volatility of comprehensive income under IAS 39 is more relevant than net income. Similarly, Hodder et al., (2006) showed that income volatility recognition at fair value under FASB reflects the actual volatility than other measures of income and therefore the fair value increases relevance. These reasons lead us to inquire to what extent the accounting information at fair value with its volatile nature improves relevance. Therefore, our second hypothesis is as follows:

$\mathrm{H}_{2}$ : the risk relevance of accounting income (volatility of earnings) has an increasing function in the evaluation dimension of the fair value of financial assets and liabilities (FFVI $>C I>N I)$.

NI is the net income for firm, CI is the comprehensive income of firm . FFVI is the full fair value income of the firm.

\section{Methodology}

In this section, we present our sample, models, variables, and tests. Besides, we discuss the descriptive statistics for our sample data.

\subsection{The sample}

Financial institution's balance sheets consist almost entirely of financial instruments. Therefore, our sample considers French financial institutions listed in the SBF 250 establishing their consolidated accounts in accordance with IAS / IFRS, including IAS 32, IAS 39 and IFRS 7. Since the application of IAS / IFRS has been introduced in the European Union starting from 2005, we focused on the period between 2005 and 2011. We identified 126 firm-years observations for this sample in this period of time.

All data has been removed from this site, Yahoo Finance. Most of the data in fair value were collected manually from notes to financial statements. Other accounting variables were removed from the consolidated balance sheets and the market variable is calculated from the same site.

\subsection{Regressions Analysis}

Model 1: the value relevance of accounting income: To assess the impact of the recognition at fair value of financial instruments on the relevance of the accounting income, we use the concept of difference and compare the sensitivity of stock returns to income measures; a relevance comparison of the three measures of income. Thus, following previous studies, this relationship can be explained by the following equations:

$$
S R_{i t}=\alpha_{0}+\alpha_{1} \text { Value Re levance }{ }_{i t}+\alpha_{2} C V_{i t}+\varepsilon_{i t}
$$

Where SR is Stock return. Value relevance is measured by three possible measures: NI is the net income for firm $\mathrm{i}$ in year $\mathrm{t}, \mathrm{CI}$ is the comprehensive income of firm $\mathrm{i}$ in year t. FFVI is the full fair value income of the firm $i$ in year $\mathrm{t}$. $\mathrm{CV}$ is control variables measured by firm size 
(SIZE is measured by log of total assets ) and the Leverage of the firm (Lev: measured by long-term liabilities divided by total assets at the end of year $t$ ). According to this formulation, we run three regressions (REG1, REG2, REG3) following the measure of the value relevance as presented above.

Our formulation combines different models in the literature. Previous studies have investigated the relevance of accounting information at fair value through the presentation of stock returns based on accounting variables. Beltrati et al., (2013) used the net income, write-down in the fair value and the historical cost as explanatory variable. Livne et al., (2011) used the financial assets and liabilities measured at fair value. The comparison between different outcome measures was presented by Duh et al. (2012) who used net income and comprehensive income. Hodder et al. (2006) (RN, CI, FFVI) when they examining the risk relevance of income volatility, they used the three form of fair value. Duh et al. (2012) used SIZE and LEV with earnings volatility as an endogenous variable.

Model 2: the risk relevance of accounting income: To test the risk relevance of accounting income, we explain the relationship between the volatility of stock returns and our explanatory variables by using models similar to equations (1). Therefore, we present the parameter of the risk; volatility is a qualitative characteristic of accounting information at fair value. Thus, our equations are:

$\operatorname{VOL}\left(S R_{i t}\right)=\lambda_{0}+\lambda_{1} \operatorname{VOL}\left(V R_{i t}\right)+\lambda_{2} M C V_{i t}+u_{i t}$

Where $\operatorname{VOL}\left(S R_{i t}\right)$ is the standard deviation of stock return; $\operatorname{VOL}\left(V R_{i t}\right)$ is the standard deviation of value relevance as measured by standard deviation of net income (VOLNI), the standard deviation of comprehensive income (VOLCI) and the standard deviation of full fair value income. MCV is the mediane of the controle variable : MLEV is the median of leverage in year t. MSIZE is the median of the size in year $t$. The model 2 is then tested in three regressions (REG 4, REG 5, REG6) following the nature of the standard deviation of the value relevance.

\subsection{Empirical Result}

\subsubsection{Descriptive statistics}

Table 1 provides the standard deviations of the three earning measures of financial institutions for seven years from 2005. Thus, the standard deviation tells us about the level of the earning volatility. If the standard deviation is low, the values may spread around the mean. The average standard deviation of net income is $0.0873 \%$ and the Standard Deviation through the Comprehensive income is $0.088 \%$. The Standard Deviation of full fair value income is $0.0943 \%$. This means that comprehensive income is more volatile than net income and full fair value income is more volatile than comprehensive income and is more volatile than net income. This result is consistent with previous studies showing the full fair value income is more volatile than other types of income measures. However, volatility is not negative in itself. What matters is the interpretation of this volatility by users of financial 


\section{Macrothink}

International Journal of Accounting and Financial Reporting ISSN 2162-3082 2016, Vol. 6, No. 2

statements essentially investors and financial analysts. Hence, it would be useful and judicious to inquire the relevance of this volatility for investors. This is our second hypothesis.

Table 1: Descriptive statistics of model variables

\begin{tabular}{|c|c|c|c|c|}
\hline Variable & Mean & Std. Deviation & Min & Max \\
\hline \multicolumn{5}{|l|}{ Panel A : } \\
\hline SR & -0.0339986 & 0.43689 & -0.9067164 & 1.84 \\
\hline NI & 0.0408359 & 0.0873484 & -0.2351174 & 0.469104 \\
\hline CI & 0.0414022 & 0.0880393 & -0.2349745 & 0.469104 \\
\hline FFVI & 0.0386048 & 0.0943547 & -0.3530996 & 0.469104 \\
\hline SIZE & 5.735213 & 0.9364583 & 3.777825 & 7.278149 \\
\hline LEV & 0.6518395 & 0.2811123 & 0.0015961 & 1.202707 \\
\hline \multicolumn{5}{|l|}{ Panel B : } \\
\hline VOLSR & 0.4104055 & 0.2014689 & 0 & 0.8960602 \\
\hline VOLNI & 0.0368449 & 0.0383933 & 0.0014947 & 0.1196441 \\
\hline VOLCI & 0.0381708 & 0.0367938 & 0.0025144 & 0.119691 \\
\hline VOLFFVI & 0.0448338 & 0.0505148 & 0.0025194 & 0.1996635 \\
\hline MSIZE & 5.671528 & 0.9428669 & 3.820812 & 7.111544 \\
\hline MLEV & 0.6380608 & 0.2874433 & 0.0458935 & 0.9948375 \\
\hline
\end{tabular}

\subsubsection{Estimation results (findings)}

We start by reporting the results of estimating of Model 1(REG1, REG2, REG3) and then model 2 (REG4, REG5, REG6). The estimation coefficients and t-statistics are calculated for the two models in all regression specifications. Table 2 and 3 reports the estimation results. 


\section{Macrothink \\ International Journal of Accounting and Financial Reporting \\ ISSN 2162-3082 \\ 2016, Vol. 6, No. 2}

\subsubsection{Test of hypothesis $\mathrm{H}_{1}$ (Model 1)}

Table 2 presents the result of hypothesis $\mathrm{H}_{1}$ with regard to the relevance of net income, comprehensive income and full fair value income. Model 1 examines the association between accounting variables with a market variable which is the stock return. The difference between these models is due to the change in the form of the income according to the principle of assessment.

Regression 1 tests the relevance of net income. The results show that net income (NI) is positively related to the stock return (SR), but does not affect it significantly. We find that the size of firms and the constant affect significantly affect the stock return. The size of firms is negatively related to the stock return.

Regression 2 results are different from Regression 1. Comprehensive income (CI) is positively related to stock return and affects it significantly. The variable SIZE is negatively and significantly related to stock return.

Regression 3 shows that the full fair value income (FFVI) is positively related to stock return. It affects considerably the stock return. Similarly, the SIZE variable and constant significantly affect the stock return.

Table 2: Relevance of income measurements

\begin{tabular}{|l|l|l|l|}
\hline & Regression 1(NI) & Regression 2 (CI) & Regression 3(FFVI) \\
\hline Constant & $\begin{array}{l}\mathbf{5 . 4 9 6 8} \\
(\mathbf{2 . 7 9}) * * *\end{array}$ & $\begin{array}{l}\mathbf{5 . 1 6 3 7} \\
(\mathbf{2 . 6 3})^{*}\end{array}$ & $\begin{array}{l}\mathbf{5 . 2 5 5 6} \\
(\mathbf{2 . 8 0})^{* * * *}\end{array}$ \\
\hline SIZE & $\begin{array}{l}\mathbf{- 0 . 9 0 7 4} \\
(-2.66)^{* * *}\end{array}$ & $\begin{array}{l}\mathbf{- 0 . 8 8 6 9} \\
\mathbf{( - 2 . 6 2 )}\end{array}$ & $\begin{array}{l}\mathbf{- 0 , 9 0 4 4 0 3 6} \\
\mathbf{( - 2 , 7 5})^{* * *}\end{array}$ \\
\hline LEV & $-0,57529$ & -0.28346 & -0.278 \\
$(0,67)$ & $(-0.33)$ & $(-0.36)$ \\
\hline NI & 1.195496 & - & - \\
\hline CI & $(1,27)$ & $\mathbf{1 . 7 8 9 9}$ & $(\mathbf{1 . 8 8}) * *$ \\
\hline
\end{tabular}




\begin{tabular}{|l|l|l|l|}
\hline Adjusted $\boldsymbol{R}^{2}$ & 0.112 & 0.1284 & 0.1743 \\
\hline Ficher test & 4,29 & 5,01 & 7,18 \\
\hline Hausman test & 0,019 & 0,0135 & 0,0037 \\
\hline
\end{tabular}

(.) $T$ student; *** significances at 1\%: if probability to <à 1\%. ** Significances at 5\%: if probability to <à 5\%. * Significances at 10\%: if probability to <à $10 \%$.

Finally, comparing the three models, we can conclude that full fair value income (FFVI) affects stock return more than the other types of income measurements and that comprehensive income affects stock return more than net income. These interpretations show with others previous studies that full fair value income is more relevant than comprehensive income. The latter is more relevant than net income. We then verify FFVI > CI > NI (H1 is confirmed).

\subsubsection{Test of hypothesis $\mathrm{H}_{2}$}

Table 3 presents the result of hypothesis $\mathbf{H}_{2}$ with regard to the relevance of net income volatility, comprehensive income volatility and full fair value income volatility. The models examine the association between income volatility and the volatility of stock returns. As in the first hypothesis, the difference between these regressions (REG4, REG5, and REG6) is due to the change in the form of the income measures according to the principle of assessment. However, in this stage, we take into account volatility. Model two (REG4) indicates that the volatility of net income (VOLNI) does not significantly affect stock returns. Therefore, it is not a relevant assessment. Again, For Regression 5 based on comprehensive income (VOLCI) does not significantly affect stock returns. Only the full fair value income (VOLFFVI) significantly affects stock returns.

Table 3: Relevance of income volatility

\begin{tabular}{|l|l|l|l|}
\hline & REG 4 (VOLNI) & REG 5 (VOLCI) & REG 6 (VOLFFVI) \\
\hline Constant & $\begin{array}{l}1.6492 \\
(1.15)\end{array}$ & $\begin{array}{l}0.12084 \\
(0.33)\end{array}$ & $\begin{array}{l}-0.09381 \\
(-0.28)\end{array}$ \\
\hline MSIZE & $\begin{array}{l}0.05803 \\
(0.11)\end{array}$ & $\begin{array}{l}0.002683 \\
(0.05)\end{array}$ & $\begin{array}{l}0.0142 \\
(0.32)\end{array}$ \\
\hline MLEV & $\mathbf{0 . 3 4 5 3 6}$ & $\mathbf{0 . 3 3 4 5}$ & $\begin{array}{l}0.4948 \\
(2.71)\end{array}$ \\
\hline
\end{tabular}




\section{Macrothink \\ International Journal of Accounting and Financial Reporting \\ ISSN 2162-3082 \\ Mnstitute

\begin{tabular}{|l|l|l|l|}
\hline VOLNI & $\begin{array}{l}1.6492 \\
(1.15)\end{array}$ & - & - \\
\hline VOLCI & - & $\begin{array}{l}1.5956 \\
(1.08)\end{array}$ & - \\
\hline VOLFFVI & - & - & $\mathbf{2 . 3 9 8 6}$ \\
\hline Adjusted $\mathrm{R}^{2}$ & 0,1803 & $\mathbf{2 . 2 7})^{* *}$ \\
\hline Fisher test & 1,25 & 0,173 & 0.3224 \\
\hline Hausman test & 0,7192 & 1,19 & 2,7 \\
\hline
\end{tabular}

(.) $\mathrm{T}$ de student. $* * *$ Significances at $1 \%$ : if probability is $<$ to $1 \%$. $* *$ Significances at $5 \%$ : if probability is < to $5 \%$. $*$ Significances at $10 \%$ : if probability is < to $10 \%$.

Finally, comparing the three models, we conclude that FFVI affect stock return more than other types of income measurement and that CI affect stock return more than NI. This interpretation shows with other previous studies that FFVI is more relevant than CI. The latter is more relevant than NI.

\section{Conclusion}

Accounting is closely, related to the development of the financial market. Measurement of financial instruments is a challenge in the financial market. The need to evaluate these financial assets and liabilities at their real value is determined using a new notion of presentation of accounting information, which is the fair value. Our study seeks to examine the relationship between stock returns and income measures at their fair value. Therefore, this study aims to validate or not the performance of the evaluation approach at fair value through the study of its relevance. Therefore, we compare three types of earnings measures by level (NI, CI and FFVI) in order to distinguish what is the most relevant measure and the most relevant principle presentation (fair value or historical cost). In addition, it examines the extent to which fair value is volatile and increases after adopting IAS 39 and if this volatility affects fair value accounting's relevance.

We find that the two types of fair value income measurements (CI and FFVI) are relevant value. The results of value relevant study are similar to those in other standards (SFAS 115) and in other contexts. When studying the risk relevance of income measurement, we find that only full fair value accounting is relevant. This result contradicts with that of other studies, which have deduced that comprehensive income is risk relevant. Well, despite the fact that our study is limited to a small number of financial institutions; it sheds light on the necessity 
to reform fair value standard valuation through its relevance, which witnesses today an enormous pressure.

\section{References:}

Al-Khadash.A.H., Al-yassen.S.B., 2011.Risk relevance of fair value income measures under IAS39 and IAS40. Journal of accounting in emerging economics. Vol.1, No1, pp. 9-32.

Barlev.B., Haddad.J.R., 2003. Fair value accounting and the management of the firm. Critical perspective on accounting -vol 14- issue 4, May 2003.

Barth M.E., Beaver W.H. and Landsman W. (1996) «Value relevance of banks' fair value disclosures under SFAS n $107 »$, the Accounting Review, vol. 71, n 4, octobre, pp. 513-537.

Barth,E.M., Landsman,W.R., Wahlen,J., 1994. Fair value accounting: effect on banks' earnings volatility, regulatory capital, and value of contractual cash flows. Journal of Banking and Finance. 19, pp. 577-605.

Barth,E.M., Landsman.R.W.,1995.Fundamental issues related to using fair value accounting for financial reporting. Accounting Horizons, 94, pp. 97-107.

Beltratti,A., Spear,N., Szabo,M.D., 2013. The value relevance and timeliness of write downs during the financial crisis of 2007-2009. The international journal of accounting . 48, pp. 467-494.

Duh.R.R., Hsin hsu.W.A., Alves.P. A.P., 2012. The impact of IAS 39 on the risk relevance of earnings volatility: evidence from foreign bank cross-listed in the USA. Journal of contemporary accounting and economics. 8 pp 23-38.

Hirst.E.D., Hopkins.E.P., Wahlen.M.J.,2004.Income measurement and bank analysts 'risk and valuation judgments. The accounting review. Vol.79,No.2 pp453-472.

Hodder,L., Hopkins, P., Wahlen.J.,2006. Risk-relevance of fair value income measures for commercial banks. The accounting review. 81, pp.337-375.

International accounting standard 39 (IAS39): Financial Instruments: Recognition and Measurement. Available on line at http://www.iasplus.com.

International accounting standard 39 (IAS39), "financial instruments: Recognition and Measurement". Available on line at www.cga-pdnet.org.

Khurana,K.I., Kim.M.S., 2003. Relative value relevance of historical cost vs fair value: evidence from bank holding companies. Vol.22, issue 1, pp 19-42.

Laux.C., Leuz.C.,2009. The crisis of fair value accounting: Making sense of the recent debate. Accounting organization and society. 34, pp 826-834.

Laux.C., Leuz.C.,2010. Did Fair-Value Accounting Contribute to the Financial Crisis? Journal of Economic Perspectives. Vol.24, Number 1_Winter 2010, pp 93-118.

Livne.G., Markarian.G., Milne. A., 2011. Bankers' compensation and fair value accounting. 


\section{Macrothink}

Journal of corporate Finance. vol.17, pp. 1096-1115.

Nelson K. (1996) «Fair value accounting for commercial banks: an empirical analysis of SFAS n¹07 », The Accounting Review, vol. 71, n² 2, avril, pp. 161-182.

Ryan,S., 2008. Accounting in and for the subprime crisis. The Accounting Review 83, 16051638.

\section{Copyright Disclaimer}

Copyright for this article is retained by the author(s), with first publication rights granted to the journal.

This is an open-access article distributed under the terms and conditions of the Creative Commons Attribution license (http://creativecommons.org/licenses/by/3.0/). 